\title{
Seroprevalence of Immunoglobulin G (IgG) and Immunoglobulin M (IgM) and Risk Factors of Toxoplasmosis for A sample of Pregnant Women in Baghdad
}

\author{
Huda Sahib Abdul Mohammed Al-Rawazq *
}

\begin{abstract}
Background: Toxoplasmosis is a very common infection caused by the obligate intracellular protozoan parasite. This parasite is called Toxoplasma gondii widely distributed around the world. Toxoplasma gondii can be vertically transmitted to the fetus during pregnancy and may cause wide range of clinical manifestations in the offspring.

Objective: To determine seroprevalence Immunoglobulin G (IgG) and Immunoglobulin M (IgM ) to toxoplasma gondii among pregnant women and to identify the risk factors.

Type of the study: A cross-sectional study.

Methods: A total of 110 blood samples of pregnant women were collected from private laboratory for Dr. luay Ibrahim to Pathogenesis Analyses in Baghdad AlMansour- 14 Ramadan street. Which obtained during the period from 1st March 2016 till the 30th June 2016. Data was collected by using direct interviewing questionnaire sheet concerning their ages of pregnant women between (less than 20 to more than 40 years old), place of residence ( urban, rural), level of education (illiteracy, literacy), number of pervious abortion (one, two, three or more), contact with ( cat and other domestic animal or no animal in house). The diagnosis is based on $\operatorname{lgG}$ and $\operatorname{lgM}$ antibodies of Toxoplasma gondii were measured using a commercial Kit ( Cobas Toxo IgG, Toxo IgM) according to the Roche Diagnostic manufacturer's instructions. Each blood was analyzed for the presence of Toxoplasma gondii by identifying serum
\end{abstract}

$\lg G$ and $\lg M$ antibodies using Enzyme-linked Immunosorbent Assay (ELISA).

Results: A total of 110 pregnant women were enrolled and screened for the presence of anti- toxoplasma IgG and IgM antibodies. The seroprevalence of Toxoplasma gondii $\lg G$ and $\operatorname{lgM}$ antibodies result revealed that 40 $(63.4 \%)$ of 110 pregnant women were positive for antitoxoplasma-antibody IgG and $70(63.6 \%)$ of 110 were negative for anti-toxoplasma-antibody-lgG while revealed that $16(13.6 \%)$ of 110 pregnant women were positive for anti-toxoplasma-antibody $\operatorname{lgM}$ and 94 (86.4\%) of 110 were negative for anti-toxoplasma-antibody $\operatorname{lgM}$.

Conclusions: the present study shows that antiToxoplasma IgG Ab are higher than anti-Toxoplasma IgM $A b$ in pregnant women between the age group 20 to 30 years in literacy educational level and rural area also recorded the highest rates of seropositivity among women with only one previously abortion in contact with cats are more affected.

Key Word: Pregnant women, Toxoplasma gondii, IgG anti-Toxoplasma, IgM anti- Toxoplasma Ab.

\section{Al-Kindy College Medical Journal 2017: Vol. 13 No.2} Page: $40-45$

\section{* Anatomy Department / Medical Biology section,} College of Medicine, University of Baghdad.

Received $7^{\text {th }}$ Aug 2016, accepted in final $26^{\text {th }}$ Feb 2017 Corresponding to Huda Sahib Abdul Mohammed AlRawazq, email:s.huda2011@Yahoo.com.
T oxoplasmosis is a very common infection caused by the obligate intracellular protozoan parasite ${ }^{(1)}$. This parasite is called Toxoplasma gondii widely distributed around the world ${ }^{(2)}$. It is a facultative heterogeneous parasite whose definitive hosts are members of the family Felidae including domestic cat but is capable of infecting mammals, birds and reptiles as intermediate hosts ${ }^{(3)}$. The high prevalence of toxoplasmosis has a relationship with its mode of transmission, as it can spread very easily ${ }^{(4)}$. Two main routes of transmission have been described in humansby oral ingestion of the parasite and through placental transmission to the fetus, The organism is horizontally transmitted to humans by accidental ingestion of water, food or soil contaminated with toxoplasma gondii Oocyst or consumption of meat containing Toxoplasma gondii cysts that is eaten raw or undercooked meat from infected animal . Toxoplasma gondii can be vertically transmitted to the fetus during pregnancy and may cause wide range of clinical manifestations in the offspring depending on the gestational age at which the primary maternal infection was acquired, the virulence of the parasite and the immunologic development of the fetus ${ }^{(5,6)}$. The women may have spontaneous abortions, stillbirths, or premature delivery in addition to various fetal anomalies ${ }^{(7)}$. The frequency of severe congenital infections can be limited by early screening for specific antibodies to toxoplasma gondii in the serum of pregnant women ${ }^{(8)}$. Typically the organisms causes only a symptomatic or mild infection in pregnant women but it can cause much more serious clinical complications to the fetus, identification of these susceptible women is essential so that early treatment can offered to minimize the congenital transmission ${ }^{(9)}$. Toxoplasmosis during 
pregnancy can cause congenital infection and manifest as mental retardation and blindness in the infant, the severity of fetal disease varies inversely with gestational age at which maternal infection occurs ${ }^{(10)}$. Epidemiology studies indicate that prevalence of Toxoplasma gondii infection in pregnant women varies substantially among countries (11). Seroprevalence estimated for human population varies greatly among different countries, different geographical areas within one country and among different ethnic groups living in the same area ${ }^{(12)}$. Infection may occur in any organ, patient may have headache and disorientation drowsiness, hemiparesis, reflex changes and convulsions, encephalitis caused by Toxoplasma gondii is now recognized with great frequency in patients treated with immunosuppressive agents ${ }^{(13)}$. Treated by their own healthcare providers with spiramycin or pyrimetamine / sulfadiazine /folinic acid depending on their gestational age ${ }^{(14)}$.

\section{Methods:}

Patients: A total of 110 blood samples of pregnant women were collected from private laboratory for Dr. luay Ibrahim to Pathogenesis Analyses in Baghdad AlMansour- 14 Ramadan street. Which obtained during the period from $1^{\text {st }}$ March 2016 till the $30^{\text {th }}$ June 2016 . Data was collected by using direct interviewing questionnaire sheet concerning their ages of pregnant women between (less than 20 to more than 40 years old), place of residence ( urban, rural), level of education (illiteracy, literacy), number of pervious abortion (one, two, three or more), contact with ( cat and other domestic animal or no animal in house).

Blood sample withdrawn from each woman by Professional clinical laboratory technique. Venous blood samples $5 \mathrm{ml}$ was collected after disinfected of skin by $70 \%$ alcohol and then blood was poured in plain container and centrifugation at $3000 \mathrm{rpm}$ for 5 minutes to obtain the serum. The serum was stored at $-20 \circ \mathrm{C}$ until analysis. Each blood was analyzed for the presence of Toxoplasma gondii by identifying serum IgG and IgM antibodies using Enzyme-linked Immunosorbent Assay (ELISA). The diagnosis is based on $\lg G$ and $\lg M$ antibodies of Toxoplasma gondii were measured using a commercial Kit (Cobas Toxo IgG, Toxo IgM) according to the Roche Diagnostic manufacturer's instructions.

Statistical Analysis: The suitable statistical methods were used in order to analyze and assess the results, they include the followings:

Descriptive statistics: Statistical tables including observed frequencies with their percentages.

Inferential statistics: These were used to accept or reject the statistical hypotheses, Persons Chi-Square test ( $\mathrm{X} 2)$ at level of significance 0.05 .

$\mathrm{P}$ value $<0.05$ level of significance was considered statistically significant.

Results: A total of 110 pregnant women were enrolled and screened for the presence of anti- toxoplasma IgG and IgM antibodies. The seroprevalence of Toxoplasma gondii $\lg G$ and $\lg M$ antibodies are given in Table (1) the result revealed that $40(63.4 \%)$ of 110 pregnant women were positive for anti-toxoplasma-antibody $\operatorname{lgG}$ and 70 $(63.6 \%)$ of 110 were negative for anti-toxoplasmaantibody-lgG while revealed that 16 (13.6\%) of 110 pregnant women were positive for anti-toxoplasmaantibody $\operatorname{lgM}$ and 94 (86.4\%) of 110 were negative for anti-toxoplasma-antibody lgM.

Table (1): Distrubution according to the seropositivity rates by ELISA (IgG, IgM) of pregnant women:

\begin{tabular}{|c|r|r|r|}
\hline ELISA Result & $\begin{array}{r}\text { Positive } \\
\%\end{array}$ & $\begin{array}{r}\text { Negative } \\
\%\end{array}$ & Total \\
\hline Anti-Toxo-Ab (IgG) & 40 & 70 & $\begin{array}{r}110 \\
(36.4)\end{array}$ \\
& $(63.6)$ & $(100.0)$ \\
\hline Anti-Toxo-Ab (IgM) & $\begin{array}{r}16 \\
(13.6)\end{array}$ & $\begin{array}{r}94 \\
(86.4)\end{array}$ & $\begin{array}{r}110 \\
(100.0)\end{array}$ \\
\hline Persons & 0.000 & 0.000 & 0.000 \\
Chi-Square & $\mathrm{S}$. & $\mathrm{S}$. & $\mathrm{S}$. \\
\hline
\end{tabular}

\section{P-Value $<0.05$}

\section{$($ Significant $=$ S.,$\quad$ Non-significant $=$ N.S. $)$}

In Table (2) show the seropositivity was observed higher in the age group between 20 to 30 years 26 (37.1), 12 (17.1) for Toxo-lgG , IgM respectively whereas it was lower for other age group.The seropositivity rates among women according to their level of education show in table (3) the highest rates were recorded for anti-lgG, IgM antibody $30(33.0 \%)$ and $11(12.1 \%)$ respectively for literacy.In the prevalence of anti-Toxo- IgG $\mathrm{Ab}$ and anti- Toxo- IgM Ab were found to be higher in rural area $30(40.0 \%)$ and $10(13.3 \%)$ respectively than in urban show in Table (4). The highest rates of seropositivity among previously aborted was recorded in women with only previously aborted which was 20 (46.5\%) for AntiToxo- IgG Ab and 7 (16.3\%) for Anti-Toxo- IgM Ab show in table (5). The rate of seropositivity of Toxoplasma gondii among women who had cats as pet animal was significantly higher 28 (70.0\%) for Anti- Toxo- IgG Ab and $11(27.5 \%)$ for Anti-Toxo- IgM Ab show in table (6). Discussion: Toxoplasma gondii leads to many serious health complications, It has been estimated that one third of the world population is infected by Toxoplasma gondii ${ }^{(15)}$. In the present study the seroprevalence of anti-IgG and IgM antibodies in pregnant women are 40 $(36.4 \%)$ and $16(13.6 \%)$ respectively this show in table (1). A slightly higher prevalence was reported by Munoza et al. ${ }^{(16)}$, Paschale et al. (17), Kamal et al. (18) And there is significant differences between anti-lgG , IgM antbodies $(P<0.05)$. Table $(2)$ show the seropositivity was observed higher in the age group between 20 to 30 years, whereas it was lower for other age group which is similar to those found with the study of Malarvizhi et al. ${ }^{(9)}$, Hung et al. ${ }^{(19)}$, Bahaeldin et al. (20) 
Table (2): The seropositivity rates by ELISA Toxo . IgM and Toxo. IgG according to age groups (Years).

\begin{tabular}{|c|c|c|c|c|c|c|}
\hline \multirow[b]{2}{*}{ Age Groups } & \multicolumn{2}{|c|}{ Toxo lgG } & \multirow[b]{2}{*}{ Total } & \multicolumn{2}{|c|}{ Toxo IgM } & \multirow[b]{2}{*}{ Total } \\
\hline & $\begin{array}{c}\text { Positive } \\
\%\end{array}$ & $\begin{array}{c}\text { Negative } \\
\%\end{array}$ & & $\begin{array}{c}\text { Positive } \\
\%\end{array}$ & $\begin{array}{c}\text { Negative } \\
\%\end{array}$ & \\
\hline$<20$ & $4(40.0)$ & $6(60.0)$ & $10(100.0)$ & $0(0.0)$ & $10(100.0)$ & $10(100.0)$ \\
\hline $20-30$ & $26(37.1)$ & $44(62.9)$ & $70(100.0$ & $12(17.1)$ & 58 (82.9) & $70(100.0)$ \\
\hline $31-40$ & $10(40.0)$ & $15(60.0)$ & $25(100.0)$ & $3(12.0)$ & $22(88.0)$ & $25(100.0)$ \\
\hline$>40$ & $0(00.0)$ & $5(100.0)$ & $5(100.0)$ & $0(00.0)$ & $5(100.0)$ & $5(100.0)$ \\
\hline Total & $40(36.4)$ & $70(63.6)$ & $110(100.0)$ & $15(13.6)$ & $95(86.4)$ & $110(100.0)$ \\
\hline $\begin{array}{l}\text { Persons Chi- } \\
\text { Square }\end{array}$ & & $\begin{array}{c}P=0.380 \\
\text { N. S. }\end{array}$ & & & $P=0.3$ & \\
\hline
\end{tabular}

P-Value > 0.05

Table (3): Association between IgG anti-Toxoplasma Ab and IgM anti-Toxoplasma Ab with the level of Education.

\begin{tabular}{|c|c|c|c|c|c|c|}
\hline \multirow{2}{*}{$\begin{array}{c}\text { Level of } \\
\text { Education }\end{array}$} & \multicolumn{2}{|c|}{ IgG anti-Toxo Ab } & \multirow{2}{*}{ Total } & \multicolumn{2}{|c|}{ IgM anti-Toxo Ab } & \multirow{2}{*}{ Total } \\
\cline { 2 - 3 } & Positive \% & Negative \% & & Positive \% & Negative \% \\
\hline illiteracy & $10(52.6)$ & $9(47.4)$ & $19(100.0)$ & $5(26.3)$ & $14(73.7)$ & $19(100.0)$ \\
\hline literacy & $30(33.0)$ & $61(67.0)$ & $91(100.0)$ & $11(12.1)$ & $80(87.9)$ & $91(100.0)$ \\
\hline Total & $40(36.4)$ & $70(63.6)$ & $110(100.0)$ & $16(14.5)$ & $94(85.5)$ & $110(100.0)$ \\
\hline Persons & \multicolumn{3}{|c|}{$\mathrm{P}=0.121$} & & & P $=0.148$ \\
Chi-Square
\end{tabular}

P-Value $>0.05$

Table (4): Association between the seropositivity rates by ELISA (IgG, IgM) and the residence.

\begin{tabular}{|c|c|c|c|c|c|c|}
\hline \multirow{2}{*}{ Residence } & \multicolumn{2}{|c|}{ Anti-Toxo Ab (IgG) } & \multirow{2}{*}{ Total } & \multicolumn{2}{|c|}{ Anti-Toxo Ab (IgM) } & \multirow{2}{*}{ Total } \\
\hline & Positive \% & Negative \% & & Positive \% & Negative \% & \\
\hline Urban & $10(28.6)$ & $25(71.4)$ & $35(100.0)$ & $4(11.4)$ & $31(88.6)$ & $35(100.0)$ \\
\hline Rural & $30(40.0)$ & $45(60.0)$ & $75(100.0)$ & $10(13.3)$ & $65(86.7)$ & $75(100.0)$ \\
\hline Total & $40(36.4)$ & $70(63.6)$ & $110(100.0)$ & $14(12.7)$ & 96 (87.3) & $110(100.0)$ \\
\hline Persons & \multicolumn{3}{|c|}{$P=0.291$} & \multicolumn{3}{|c|}{$P=1.000$} \\
\hline Chi-Square & \multicolumn{3}{|c|}{ N.S. } & \multicolumn{3}{|c|}{ N.S. } \\
\hline
\end{tabular}


Table (5): Association between the seropositivity rates by ELISA (IgG, IgM) and the number of previous abortion.

\begin{tabular}{|c|c|c|c|c|c|c|}
\hline \multirow{2}{*}{$\begin{array}{c}\text { No. of } \\
\text { Previous } \\
\text { abortion }\end{array}$} & \multicolumn{2}{|c|}{ Anti-Toxo Ab (IgG) } & \multirow{2}{*}{ Total } & \multicolumn{2}{|c|}{ Anti-Toxo Ab (IgM) } & \multirow{2}{*}{ Total } \\
\hline & Positive \% & Negative $\%$ & & Positive \% & Negative \% & \\
\hline one & $20(46.5)$ & $23(53.5)$ & $43(100.0)$ & $7(16.3)$ & $36(83.7)$ & $43(100.0)$ \\
\hline two & 11 (64.7) & 6 (35.3) & $17(100.0)$ & $7(41.2)$ & $10(58.8)$ & $17(100.0)$ \\
\hline Three & $1(100.0)$ & $0(00.0)$ & $1(100.0)$ & $1(100.0)$ & $0(00.0)$ & $1(100.0)$ \\
\hline $\begin{array}{c}\text { No } \\
\text { Abortion }\end{array}$ & $8(16.3)$ & 41 (83.7) & $49(100.0)$ & $1(2.0)$ & $48(98.0)$ & $49(100.0)$ \\
\hline Total & $40(36.4)$ & $70(63.6)$ & $110(100.0)$ & $16(14.5)$ & $94(85.5)$ & $110(100.0)$ \\
\hline Persons & & $P=0.000$ & & & $P=0.000$ & \\
\hline Chi-Square & & S. & & & S. & \\
\hline
\end{tabular}

\section{P-Value $<0.05$}

Table (6): Distrubution according to the seropositivity rates by ELISA (IgG, IgM) of Pregnant women contact with cats and domestic animals.

\begin{tabular}{|c|c|c|c|c|c|c|}
\hline \multirow{2}{*}{ Contact with } & \multicolumn{2}{|c|}{ Anti-Toxo Ab (IgG) } & \multirow{2}{*}{ Total } & \multicolumn{2}{|c|}{ Anti-Toxo Ab (IgM) } & \multirow{2}{*}{ Total } \\
\hline & Positive \% & Negative \% & & Positive \% & Negative $\%$ & \\
\hline Cats & $28(70.0)$ & $12(30.0)$ & $40(100.0)$ & $11(27.5)$ & $29(72.5)$ & $40(100.0)$ \\
\hline $\begin{array}{l}\text { Domestic } \\
\text { Animals }\end{array}$ & $2(100.0)$ & $0(00.0)$ & $2(100.0)$ & $1(50.0)$ & $1(50.0)$ & $2(100.0)$ \\
\hline $\begin{array}{c}\text { No } \\
\text { Animal }\end{array}$ & $10(14.7)$ & $58(85.3)$ & $68(100.0)$ & $4(5.9)$ & $64(94.1)$ & $68(100.0)$ \\
\hline Total & $40(36.4)$ & $70(63.6)$ & $110(100.0)$ & $16(14.5)$ & $94(85.5)$ & $110(100.0)$ \\
\hline Persons & & $P=0.000$ & & & $P=0.00$ & \\
\hline Chi-Square & & S. & & & S. & \\
\hline
\end{tabular}


There is non-significant differences between age group and anti-IgG, anti-IgM antibodies $(P>0.05)$. The seropositivity rates among women according to their level of education show in table (3) the highest rates were recorded for anti-IgG , IgM antibody 30 (33.0\%) and $11(12.1 \%)$ respectively for literacy while in illiteracy the rate was $10(52.6 \%), 5(26.3 \%)$ respectively the association between IgG anti Toxoplasma $\mathrm{Ab}$ and $\operatorname{lgM}$ anti-Toxoplasma $\mathrm{Ab}$ with the level of education statistically non-significance difference $(p>0.05)$ this agreement with Malarvizhi et al. ${ }^{(9)}$.In the prevalence of anti-Toxo- IgG Ab and anti- Toxo- IgM Ab were found to be higher in rural area $30(40.0 \%)$ and $10(13.3 \%)$ respectively than in urban people and agree Wam et al. ${ }^{(21)}$ show in Table (4). The highest rates of seropositivity among previously aborted was recorded in women with only previously aborted which was 20 (46.5 $\%)$ for Anti- Toxo- IgG Ab and 7 (16.3\%) for Anti-ToxoIgM Ab show in table (5) agree with Saif et al. ${ }^{(22)}$. And significance differences between the association $(p<$ $0.05)$. Although cats are the main host for Toxoplasma but is not the main route of infection worldwide ${ }^{(1)}$. The rate of seropositivity of Toxoplasma gondii among women who had cats as pet animal was significantly higher 28 (70.0\%) for Anti- Toxo- IgG Ab and 11 (27.5 $\%)$ for Anti-Toxo- IgM Ab show in table (6) than without any cat in their house this finding is in accordance with those reported by other workers Abamecha and Awel ${ }^{(23)}$ Saif et al. (22). And statistically there is significance differences between the pregnant women who has cats $(p<0.05)$.

Conclusions: In conclusion the present study shows that anti-Toxoplasma $\lg \mathrm{A} \mathrm{Ab}$ are higher than antiToxoplasma IgM $\mathrm{Ab}$ in pregnant women between the age group 20 to 30 years in literacy educational level and rural area also recorded the highest rates of seropositivity among women with only one previously abortion in contact with cats are more affected.

Recommendation: Women should be encouraged to perform tests for toxoplasmosis before and during pregnancy. There must be implementation of regular serological testing pregnancy is important to reduce the effects of the disease on mother as well as on newborn babies and there must be an educational programmed for the general public as they are given to the pregnant women because the health information and health protection strategies should be relevant to the general people.

\section{References:}

1. Nijem KI and Al-Amleh S. Seroprevalence and associated risk factors of toxoplasmosis in pregnant women in Hebron district, Plastine. East. Meditterr. Heal. J.; 2009, 15 (5): 12781284.

2. Hill DE, Chirukandoth S, Dubey JP, Biology and Epidemiology of Toxoplasma gondii in man and animals. Clin. Microbiol. Infect; 2005, 6: 4161.

3. Alkadasi MN, Putaiah ET, lamer GA, et al. Prevalence of Toxoplasmosis among Pregnant Women and Risk Factors in Al-Kaeda Province, IBB, Yemen. Indo Am. J. P. Sci; 2016 , 3(8) : 892-899.

4. Dwinata I, Sutarga I, Damriyasa I. The Potential Risk Factors for Toxoplasmosis in
Balinese Pregnant Women-Indonesia. Bali Medical Journal; 2016, 5(1): 130-133.

5. Remingtan JS, Mcleod R, Thulliez P, Desmonts G, Toxoplasmosis Chapter 31. In: Remington JS and Klein J, eds Infectious diseases of the fetus and Newborn Infant $\left(6^{\text {th }}\right.$ ed). Saunders WB, Philadelphia; 2006, 974-1092.

6. Montoya JG and Liesenfeld O. Toxoplasmosis. Lancet; 2004, 363:1965-1976.

7. Song KJ, Shin JC, Shin JC. Seroprevalence of toxoplasmosis in Korean pregnant women. Korean J. of parasite; $2005,43(2): 69-71$.

8. Szenasi Z, Horvath K, Sarkany E, Melles M. Toxoplasmosis surveillance during pregnancy and quality assurance of methods in Hungary. Wien Klin Wochenschr; 2005, 117(4): 29-34.

9. Malarvizhi A, Viswanathan T, Lavanya $\mathrm{V}$, et al. Seroprevalence of Toxoplasma gondii in pregnant women. J. of pub. Heal and Epidemio; 2012, 4(6): 170-177.

10. Ertug S, Okyay p, Turkmen $M$, Yuksel $H$. Seroprevalence and risk factors for Toxoplasma infection among pregnant women in Aydin province, Turkey. BMC public Heal; 2005, 5(66): 1 6.

11. Nash JQ, Chissel S, Jones J, et al. Risk factor for Toxoplasmosis in pregnant women in kent. United Kingdom. Epidemiol. Infect; 2005, 133:475-483.

12. Tenter AM, Heckerroth AR, Weiss LM. Toxoplasma gondii from animals to human. Inf.J. parasitol; 2000, 30: 1217-1258.

13. Hill D and Dubey JP. Toxoplasma gondii: transmission, diagnosis and prevention . Clin. Microbial infect; 2002, 8: 634-640.

14. Rosso F, Les JT, Agudelo A, et al. Prevalence

15. of infection with Toxoplasma gondii among pregnant women in Cali, Colombia, South America. Am. J. Trop. Med. Hyg ; 2008, 78(3): 504-508.

16. Montoya JG and Liesenfeld O. Toxoplasmosis. Lancet, (2004); 363 (9425): 1965-1976.

17. Munoz BC, Guardia LC, Juncosa MT, et al. Toxoplasmosis and pregnancy. Multicenter study of 16,362 pregnant women in Barcelona. Med. clin. (2004); 123: 12-16.

18. Paschale MDe, Agrappi C, Clerici $P$, et al. Seroprevalence and incidence of Toxoplasma gondii infection in the Legnano area of Italy. Clin Microbiol Infect. 2008; 14: 186-189.

19. Kamal AM, Ahmed1 AK, Abdellatif $M Z$, et al. Seropositivity of Toxoplasmosis in Pregnant Women by ELISA at Minia University Hospital, Egypt. Korean J Parasitol ; 2015, 53 (5) : 605-610.

20. Hung CC, Fan CK, Su -E, et al. Serological screening and toxoplasmosis exposure factors among pregnant women in the Democrats Republic of Sao Tome and Principe. Trans.

21. Bahaeldin K. Elamin and Sara E. Elturabi. Seroprevalence of toxoplasmosis among women with abortion in Khartoum State. J Coast. Lif. Medi; 2015, 3 (7): 551-554.

22. Wam EC, Sama LF, Ali1 IM, et al. Seroprevalence of Toxoplasma gondii IgG and IgM antibodies and associated risk factors in women of child-bearing age in Njinikom, NW Cameroon. BMC Res Notes; 2016, 9 (406): (1-8). 
23. Saif N, Al Ameeri G, Alhweesh M, et al. Sero Prevalence of Toxoplasmosis in Pregnant Women in Taiz-Yemen. Int. J.Curr. Microbiol. App. Sci ; 2014, 3(7) : 680-690

RoyalcSociety Tropical

Med.Hygiene,(2007):101.139-134
24 Abamecha F. and Awel H. Seroprevalence and risk factors of Toxoplasma gondii infection in pregnant women following antenatal care at Mizan Aman General Hospital, Bench Maji Zone (BMZ), Ethiopia. BMC Infectious Diseases; 2016, 16 (460): 1-8. 